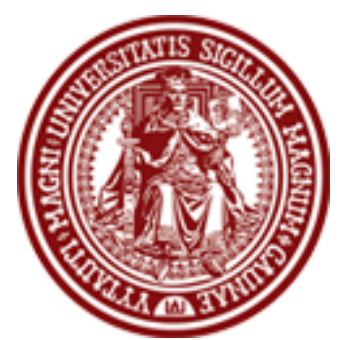

DE DE GRUYTER OPEN

\section{BALTIC JOURNAL OF LAW \& POLITICS}

A Journal of Vytautas Magnus University

VOLUME 9, NUMBER 1 (2016)

ISSN 2029-0454

\title{
A PRISONER'S RIGHT TO BE RELEASED OR PLACED ON PAROLE: A COMMENT ON ÖCALAN V TURKEY (NO. 2) (18 MARCH 2014)
}

\section{Jamil Ddamulira Mujuzi}

\author{
Associate Professor \\ University of the Western Cape, Faculty of Law (South Africa) \\ Contact information \\ Address: University of the Western Cape, Private Bag X 17, Bellville 7535, South Africa \\ Phone: +27 (0)219593286 / 3299 \\ E-mail address: djmujuzi@gmail.com
}

Received: February 12, 2016; reviews: 2; accepted: May 18, 2016.

\section{ABSTRACT}

The European Convention on Human Rights does not provide for a prisoner's right to parole and no international or regional human rights instrument provides for this right. However, recently, in the case of Öcalan v Turkey (No. 2), one of the judges of the European Court of Human Rights interpreted the European Convention on Human Rights as providing for a prisoner's right to parole. This is the first time that a judge of this court, and to the author's best knowledge, a judge of a regional or international court, has expressly held that a prisoner has the right to parole. The author assesses this holding in the light of the jurisprudence or practice on the right to parole from the Human Rights Committee, and the African Commission on Human and Peoples' Rights. In order to put the discussion in context, the author also highlights jurisprudence emanating from the European Court of Human Rights relevant to the relationship between parole and other human rights. The author 
recommends that the time has come for the right to parole to be recognised in human rights instruments.

\section{KEYWORDS}

Parole, European Court of Human Rights, prisoners, comparative law, release

\section{NOTE}

This article was finalized when I was a visiting researcher at the School of Law, the University of Nottingham, United Kingdom (July 2016). I am grateful to Professor Dirk van Zyl Smit for hosting. My stay at the University of Nottingham was supported partly by the National Research Foundation of South Africa (Grant specific unique reference number (UID) 86004). I acknowledge that the opinions, findings, conclusions and recommendations expressed in this paper are strictly my own and that the NRF accepts no liability whatsoever in this regard. 


\section{INTRODUCTION}

In Ezeh and Connors $v$ the United Kingdom, ${ }^{1}$ judges Zupančič and Maruste observed that:

One should keep in mind that probation and parole in criminal law have, ever since their inception in the nineteenth century, been predicated upon the positive and flexible - that is, non-rigid and non-formalistic - prospect of rewarding prisoners' good behaviour. The historic success of both parole (conditional release) and probation (conditional sentence) is explained by this positive and lasting influence the rewarding of good behaviour has on the personality of the convicted criminal. ${ }^{2}$

Much as the placement of an offender on parole is an integral part of the criminal justice system, the European Convention on Human Rights does not provide for a prisoner's right to parole. No international or regional human rights instrument provides for this right. Most of the jurisprudence from the European Court of Human Rights is to the effect that an offender does not have a right to parole. For example, in Arvydas Živulinskas $v$ Lithuania $^{3}$ in declaring the applicant's application as inadmissible, the European Court of Human Rights (Second Section) held that:

[T] he applicant complained under Article 6 of the Convention that he had been unable to obtain his conditional release, alleging various procedural irregularities in the parole proceedings. The Court recalls, however, that the Convention does not guarantee, as such, the right to parole or release on licence. A sentence of imprisonment after conviction by a competent court is justified at the outset by the original trial and appeal proceedings. Moreover, Article 6 is not applicable to parole proceedings as they do not involve the determination of a criminal charge, or civil right or obligation $\ldots . .4$

There are also other judgments in which the Court held that an offender does not have a right to parole. ${ }^{5}$ The European Committee on Crime Problems observed in the context of Lithuania that "[t]he right to parole depends on the crime committed: a person has a right to apply for parole after serving $1 / 3-3 / 4$ of the imprisonment sentence." ${ }^{\prime 6}$ It should be noted, however, that the relevant legislation

\footnotetext{
1 Ezeh and Connors $v$ The United Kingdom, Applications nos. 39665/98 and 40086/98 (October 9, 2003).

2 Ibid. (Dissenting Opinion of Judges Zupančič and Maruste), para 15.

3 Arvydas Živulinskas v Lithuania, Application no. 34096/02 (December 12, 2006).

4 Ibid., para 7.

5 Öcalan v Turkey (No. 2), Applications nos. 24069/03, 197/04, 6201/06 and 10464/07 (March 18, 2014) (Partly Dissenting Opinion of Judge Pinto De Albuquerque), footnote 25.

${ }^{6}$ European Committee on Crime Problems, Council for Penological Co-operation, "Dangerous Offenders Country Survey," PC-CP (2010) 04 (March 15, 2010): 12 //
} 
in Lithuania does not provide for the right to parole. It provides for the durations that offenders have to serve before they may be placed on parole. ${ }^{7}$ The European Committee for the Prevention of Torture noted with concern that in Bulgaria some prisoners sentenced to life imprisonment "had no right to parole." ${ }^{8}$ Recently, in the case of Öcalan $v$ Turkey (No. 2), ${ }^{9}$ one of the judges of the European Court of Human Rights interpreted the European Convention of Human Rights as providing for a prisoner's right to parole. This is the first time that a judge of this court, and to the author's best knowledge, a judge of a regional or international court, has expressly held that a prisoner has the right to parole. This explains why this judgement is very important. Based on jurisprudence from international human rights bodies and from courts and legislation from different countries, I argue that there is evidence of the move towards recognising a prisoner's right to be released on parole. This is a case where a prisoner has served the required non-parole period and his continued imprisonment cannot be justified on grounds such as dangerousness. I argue that the continued imprisonment of a prisoner in such circumstances could also violate his right not to be deprived of liberty arbitrary. The article begins by highlighting the jurisprudence of the European Court of Human Rights on the relationship between human rights and parole.

\section{THE RELATIONSHIP BETWEEN HUMAN RIGHTS AND PAROLE: JURISPRUDENCE OF THE EUROPEAN COURT OF HUMAN RIGHTS}

The issue of the release or placement of prisoners on parole has been considered by the European Court of Human Rights in different cases. Because most of these cases do not deal with irreducible life sentences, their detailed discussion falls outside the scope of this article. These cases have dealt with issues such as the following: the unjustified continued imprisonment of the offender after the revocation of his parole as a violation of his right to liberty; ${ }^{10}$ the continued imprisonment of the applicant after his qualification for parole as a violation of the right to liberty; ${ }^{11}$ the delay in reviewing the applicant's eligibility for

http://www.coe.int/t/dghl/standardsetting/prisons/PCCP\%20documents\%202010/PC-

CP(2010)04_E\%20_Dangerous\%200ffenders\%20per\%20Country.pdf.

7 See Articles 77 and 94 of the Law on the Approval and Entry into Force of the Criminal Code, September 26, 2000, No VIII-1968 [As last amended on February 11, 2010 - No XI-677].

8 "Report to the Bulgarian Government on the visit to Bulgaria carried out by the European Committee for the Prevention of Torture and Inhuman or Degrading Treatment or Punishment (CPT) from 4 to 10 May 2012," CPT/Inf (2012) 32, para 32, footnote 17. See also "Report to the Bulgarian Government on the visit to Bulgaria carried out by the European Committee for the Prevention of Torture and Inhuman or Degrading Treatment or Punishment (CPT) from 15 to 19 December 2008, " CPT/Inf (2010) 29, para 68.

9 Öcalan $v$ Turkey (No. 2), supra note 5.

10 Stafford $v$ The United Kingdom, Application no. 46295/99 (May 28, 2002).

11 Del Río Prada v Spain, Application no. 42750/09 (October 21, 2013). 
parole violated his right to liberty; ${ }^{12}$ the delay in releasing an ill prisoner on medical parole violated his right not to be subjected to inhuman or degrading treatment; ${ }^{13}$ extraditing a person to a country where he will be sentenced to an irreducible life sentence or a grossly disproportionate sentence was contrary to article 3 of the Convention; ${ }^{14}$ the body responsible for deciding whether or not an offender's placement on parole should be cancelled has to be legally established and constituted; ${ }^{15}$ the parole board which is empowered to decide whether or not the offender should be placed on parole should be legally empowered to exercise such powers; ${ }^{16}$ an offender who poses a risk to the public may be imprisoned indefinitely; ${ }^{17}$ parole legislation should not be applied discriminatory; ${ }^{18}$ the parole board has to exercise its powers independently and impartially; ${ }^{19}$ whether a public broadcaster may broadcast information disclosing the details of an offender released on parole; ${ }^{20}$ and that a victim of crime has no right to be informed when the offender is being considered for placement on parole. ${ }^{21}$

The European Court of Human Rights has developed rich jurisprudence relating to the issue of releasing on parole offenders sentenced to life imprisonment. As indicated above, the Court has held that extraditing a person to a country where he will be sentenced to an irreducible life sentence would be contrary to Article 3 of the European Convention on Human Rights. The Court has held that offenders sentenced to life imprisonment should have the prospect of being

12 Oldham $v$ The United Kingdom, Application no. 36273/97 (September 26, 2000). See also Blackstock $v$ The United Kingdom, Application no. 59512/00 (June 21, 2005).

13 Mouisel v France, Application no. 67263/01 (November 14, 2002). See also Gelfmann v France, Application no. 25875/03 (December 14, 2004); Nogin v Russia, Application no. 58530/08 (January 15, 2015); Koryak v Russia, Application no. 24677/10 (November 13, 2012); Stoyan Mitev v Bulgaria, Application no. 60922/00 (January 7, 2010); Ivko v Russia, Application no. 30575/08 (December 15, 2015); Vasyukov v Russia, Application no. 2974/05 (April 5, 2011).

14 Trabelsi v Belgium, Application no. 140/10 (September 4, 2014); Othman (Abu Qatada) v The United Kingdom, Application no. 8139/09 (January 17, 2012), para 206; Babar Ahmad and Others $v$ The United Kingdom, Applications nos. 24027/07, 11949/08, 36742/08, 66911/09 and 67354/09 (April 10, 2012); Aswat $v$ The United Kingdom, Application no. 17299/12 (April 16, 2013); Harkins and Edwards $v$ The United Kingdom, Application nos. 9146/07 and 32650/07 (January 17, 2012); Rrapo v Albania, Application no. 58555/10 (September 25, 2012), para 90.

${ }_{15}$ Singh $v$ The United Kingdom, Application no. 23389/94 (February 21, 1996). See also Curley $v$ The United Kingdom, Application no. 32340/96 (March 28, 2000); Waite $v$ The United Kingdom, Application no. 53236/99 (December 10, 2002).

${ }^{16}$ Hussain $v$ The United Kingdom, Application no. 21928/93 (February 21, 1996); Von Bülow $v$ The United Kingdom, Application no. 75362/01 (October 7, 2003).

17 James, Wells and Lee $v$ The United Kingdom, Applications nos. 25119/09, 57715/09 and 57877/09 (September 18, 2012).

18 Clift $v$ The United Kingdom, Application no. 7205/07 (July 13, 2010). In Rangelov $v$ Germany, Application no. 5123/07 (March 22, 2012), para 83, the Court held that 'Article 5 of the Convention does not guarantee a right to automatic parole ... However, where procedures relating to the release of prisoners appear to operate in a discriminatory manner, this may raise issues under Article 5 of the Convention taken together with Article 14.'

19 Weeks $v$ The United Kingdom, Application no. 9787/82 (March 2, 1987). See also Thynne, Wilson and Gunnell $v$ The United Kingdom, Application no. 11787/85; 11978/86; 12009/86 (October 25, 1990); Wynne $v$ The United Kingdom (no. 2), Application no. 67385/01 (October 16, 2003).

20 Österreichischer Rundfunk v Austria, Application no. 35841/02 (December 7, 2006).

21 Rumor $v$ Italy, Application no. 72964/10 (May 27, 2014), para 72 where the Court held that the Convention may not be interpreted as imposing a general obligation on States to inform the victim of illtreatment about the criminal proceedings against the perpetrator, including about possible release on parole from prison or transfer to house arrest.' 
released in order to reintegrate into society. ${ }^{22}$ In Khoroshenko $v$ Russia ${ }^{23}$ the Court noted that the Russian "Code of Execution of Criminal Sentences mentions the possibility for a life-sentence prisoner to request release on parole after serving a period of twenty-five years" but found that "the very strict nature of the applicant's regime prevents life-sentence prisoners from maintaining contacts with their families and thus seriously complicates their social reintegration and rehabilitation instead of fostering and facilitating it." 24 Although the European Convention of Human Rights does not provide for the prisoners' right to rehabilitation, the Court has held that:

While the Convention does not guarantee, as such, a right to rehabilitation, and while Article 3 cannot be construed as imposing on the authorities an absolute duty to provide prisoners with rehabilitation or reintegration programmes and activities, such as courses or counselling, it does require the authorities to give life prisoners a chance, however remote, to someday regain their freedom. For that chance to be genuine and tangible, the authorities must also give life prisoners a proper opportunity to rehabilitate themselves. ${ }^{25}$

States have a duty to ensure that prisoners sentenced to life imprisonment have access to rehabilitation programmes. Some judges have held that an irreducible life sentence (life sentence without the prospect of release) would violate the principle of human dignity. ${ }^{26}$ The Court held that life imprisonment without real prospect of release violates Article 3 of the Convention. ${ }^{27}$ In a case against Hungary, the Court noted that the regulation relating to the release of offenders sentenced to life imprisonment must "guarantee a proper consideration of the changes and the progress towards rehabilitation made by the prisoner. ${ }^{28}$ The Court also held that a sentence of life imprisonment without the possibility of parole is not contrary to Article 3 of the European Convention on Human Rights if "national law and practice afford the possibility of a dedicated judicial review of the life sentence imposed on the applicant." 29 The above jurisprudence shows that the law and practice should provide for the possibility of releasing an offender sentenced to life imprisonment. The Court does not hold that such an offender has a right to be released on parole.

\footnotetext{
22 See Vinter and Others $v$ The United Kingdom, Applications nos. 66069/09, 130/10 and 3896/10 (July 9 , 2013) (the most important holding in this case is reproduced in footnote 33 below).

23 Khoroshenko v Russia, Application no. 41418/04 (June 30, 2015).

${ }^{24}$ Ibid., para 144.

25 Harakchiev and Tolumov v Bulgaria, Applications nos. 15018/11 and 61199/12 (July 8, 2014), para 264. See also James, Wells and Lee $v$ The United Kingdom, supra note 17; Dillon $v$ The United Kingdom, Application no. 32621/11 (November 4, 2014); David Thomas $v$ The United Kingdom, Application no. 55863/11 (November 4, 2014).

${ }^{26}$ Léger v France, Application no. 19324/02 (March 30, 2009) (Dissenting Opinion of Judge Spielmann, Joined by Judges Bratza, Gyulumyan and Jebens).

27 László Magyar v Hungary, Application no. 73593/10 (May 20, 2014).

28 Ibid., para 58 (release on the basis of presidential pardon/clemency).

29 Čačko v Slovakia, Application no. 49905/08 (July 22, 2014), para 78
} 


\title{
2. THE HOLDING ON THE RIGHT TO PAROLE IN ÖCALAN $V$ TURKEY
}

(NO. 2)

In Öcalan $v$ Turkey (No. 2), ${ }^{30}$ the European Court of Human Rights dealt with different issues all of which are not relevant to this article. Relevant to this article is the issue of the right to parole. The applicant had, after the commutation of his death sentence, been sentenced to "aggravated life imprisonment" which in effect meant "that the applicant will remain in prison for the rest of his life, regardless of any consideration relating to his dangerousness and without any possibility of parole, even after a specific period of incarceration. ${ }^{\prime 31}$ The Court found that such a sentence was in violation of Article 3 of the European Convention on Human Rights. ${ }^{32}$ It concluded that:

\begin{abstract}
Nevertheless, the Court considers that this finding of a violation cannot be understood as giving the applicant the prospect of imminent release. The national authorities must review, under a procedure to be established by adopting legislative instruments and in line with the principles laid down by the Court in paragraphs 111-113 of its Grand Chamber judgment in the case of Vinter and Others ${ }^{33} \ldots$ whether the applicant's continued incarceration is still justified after a minimum term of detention, either because the requirements of
\end{abstract}

30 Öcalan v Turkey (No. 2), supra note 5.

31 Ibid., para 201.

32 Article 3 of the European Convention on Human Rights provides that 'No one shall be subjected to torture or to inhuman or degrading treatment or punishment.'

33 Vinter and Others $v$ The United Kingdom, supra note 22, paras $111-113$ : "111. It is axiomatic that a prisoner cannot be detained unless there are legitimate penological grounds for that detention. As was recognised by the Court of Appeal in Bieber and the Chamber in its judgment in the present case, these grounds will include punishment, deterrence, public protection and rehabilitation. Many of these grounds will be present at the time when a life sentence is imposed. However, the balance between these justifications for detention is not necessarily static and may shift in the course of the sentence. What may be the primary justification for detention at the start of the sentence may not be so after a lengthy period into the service of the sentence. It is only by carrying out a review of the justification for continued detention at an appropriate point in the sentence that these factors or shifts can be properly evaluated. 112. Moreover, if such a prisoner is incarcerated without any prospect of release and without the possibility of having his life sentence reviewed, there is the risk that he can never atone for his offence: whatever the prisoner does in prison, however exceptional his progress towards rehabilitation, his punishment remains fixed and unreviewable. If anything, the punishment becomes greater with time: the longer the prisoner lives, the longer his sentence. Thus, even when a whole life sentence is condign punishment at the time of its imposition, with the passage of time it becomes - to paraphrase Lord Justice Laws in Wellington - a poor guarantee of just and proportionate punishment (see paragraph 54 above). 113. Furthermore, as the German Federal Constitutional Court recognised in the Life Imprisonment case (see paragraph 69 above), it would be incompatible with the provision on human dignity in the Basic Law for the State forcefully to deprive a person of his freedom without at least providing him with the chance to someday regain that freedom. It was that conclusion which led the Constitutional Court to find that the prison authorities had the duty to strive towards a life sentenced prisoner's rehabilitation and that rehabilitation was constitutionally required in any community that established human dignity as its centrepiece. Indeed, the Constitutional Court went on to make clear in the subsequent War Criminal case that this applied to all life prisoners, whatever the nature of their crimes, and that release only for those who were infirm or close to death was not sufficient (see paragraph 70 above).

Similar considerations must apply under the Convention system, the very essence of which, as the Court has often stated, is respect for human dignity ...." 
punishment and deterrence have not yet been entirely fulfilled or because the applicant's continued detention is justified by reason of his dangerousness. ${ }^{34}$

The Court (majority) does not hold expressly that an offender has a right to parole. It reaffirms the Grand Chamber's judgement in Vinter that an offender, irrespective of the sentence he is serving, has two rights: the right to a prospect of release and the right to a review of his sentence. ${ }^{35}$ However, in his partly dissenting opinion in Öcalan $v$ Turkey (No. 2), ${ }^{36}$ Judge Pinto De Albuquerque observed that:

In the light of Vinter, States must establish a mechanism to review the justification of continued imprisonment according to the penological needs of the prisoner sentenced to a "whole life order". If a parole mechanism must be available to those convicted of the most heinous crimes, it must a fortiori be available to the other prisoners. In other words, the Convention guarantees a right to parole, including for those convicted of the most serious crimes. This means that prisoners have a vested and enforceable right to be paroled if and when the legal requisites of parole are present, not that all prisoners should necessarily be granted parole. Moreover, parole is not a release from the sentence, but a modification of the form of state interference with the sentenced person's liberty, by way of supervision of his or her life at large. And this supervision may take a very stringent form, with strict conditions attached, according to the needs of each paroled person. ${ }^{37}$

Judge Pinto De Albuquerque added that "there are ...three basic requirements for effective protection of the prisoner's right to parole under the Convention' ${ }^{38}$ : firstly, 'the parole mechanism must be placed under the authority of a court or at least under full judicial review both of the factual and the legal elements of the decision"; ${ }^{39}$ second, "the parole review must take place within a pre-determined, reasonable timeframe"; 40 and last:

The criteria for assessing the appropriateness of parole must be established by law in a clear and foreseeable manner and be based primarily on special preventive considerations, and secondarily on general preventive considerations. Considerations of general prevention alone should not be used to justify refusal

34 Öcalan v Turkey (No. 2), supra note 5, para 207.

35 See generally Dirk van Zyl Smit, Pete Weatherby and Simon Creighton, "Whole Life Sentences and the Tide of European Human Rights Jurisprudence: What Is to Be Done?" Human Rights Law Review 14 (2014).

36 Öcalan v Turkey (No. 2), supra note 5.

37 Ibid., para 11. For the same views see "Intervention in the Council for Penological Co-Operation," Fourth Plenary Meeting (November 5, 2014): para 6 // http://www.coe.int/t/DGHL/STANDARDSETTING/PRISONS/PCCP\%20documents\%202014/CEDH\%20inte rvention\%20PC-CP\%20plenary\%20November\%202014.pdf.

38 Öcalan v Turkey (No. 2), supra note 5, para 12 (Partly Dissenting Opinion of Judge Pinto De Albuquerque).

39 Ibid.

40 Ibid., para 13. 
of parole or recall to prison. The criteria should not be limited to the prisoner's mental or physical infirmity or closeness to death. Such "compassionate grounds" are clearly too restrictive. ${ }^{41}$

The judge added that:

The existence of a clear and predictable legal framework which enshrines the right to parole of all prisoners, including those who have committed the most "heinous crimes", is an international obligation of member States, and compliance with international human rights law does not hinge on how shocking the factual circumstances of each case are. ${ }^{42}$

In the above judgement the judge makes it very clear that an offender has the right to parole and lays down the circumstances that must be in place for such a right to be protected, promoted, fulfilled and realised. The judge adopted the same approach in a subsequent case. ${ }^{43}$ In order to assess whether the above holding could have international appeal, it is helpful to have a look at the approach that some international human rights bodies have taken with regards to the issue of the prisoners' right to parole.

\section{THE RIGHT tO PAROLE IN COMPARATIVE PERSPECTIVE: INTERNATIONAL HUMAN RIGHTS BODIES}

As previously mentioned, international human rights treaties do not provide for the right to parole. However, Article 10 of the International Covenant on Civil and Political Rights provides, inter alia, that "[t]he penitentiary system shall comprise treatment of prisoners the essential aim of which shall be their reformation and social rehabilitation." The drafting history of Article 10(3) also shows that the issue of parole was not dealt with in the submissions made by states which participated in the drafting process. ${ }^{44}$ The Human Rights Committee (HRC) has not held expressly that an offender has a right to parole. The HRC has, however, held that "a life sentence without parole...may raise issues under article 7 of the Covenant, in the light of the objectives of punishment as enshrined in article 10, paragraph 3, of the Covenant."45 It has, however, held that once the offender

\footnotetext{
41 Ibid., para 14.

${ }^{42}$ Ibid.

${ }^{43}$ In Murray $v$ The Netherlands, Application no. 10511/10 (April 26, 2016), para 13 (Partly Concurring Opinion of Judge Pinto De Albuquerque) it was held that "if a parole mechanism must be available to those convicted of the most heinous crimes, a fortiori it must be available to other prisoners. It would fly in the face of justice if offenders convicted of less serious offences could not be paroled whenever they are apt to reintegrate society, while such an opportunity would be afforded to offenders convicted of more serious crimes. Thus, in principle, the Convention guarantees a right to parole to all prisoners."

44 Manfred Nowak, "U.N. Covenant on Civil and Political Rights: CCPR Commentary" (1993).

45 Weiss v Austria, Comm. No. 1821/2008, U.N. Doc. CCPR/C/106/D/1821/2008, Views (HRC, Oct. 24, 2012), para 9.4.
} 
has served the non-parole period, he must be considered for parole. The Committee held that:

The Committee considers that the remaining authors' detention for preventive purposes, that is, protection of the public, once a punitive term of imprisonment has been served, must be justified by compelling reasons, reviewable by a judicial authority, that are and remain applicable as long as detention for these purposes continues. The requirement that such continued detention be free from arbitrariness must thus be assured by regular periodic reviews of the individual case by an independent body, in order to determine the continued justification of detention for purposes of protection of the public. ${ }^{46}$

The Human Rights Committee observed in a case in which Australia sentenced juveniles to life imprisonment and they were required to serve 30 years before being considered for parole that:

The Committee considers that the imposition of life sentences on the authors as juveniles can only be compatible with article 7, read together with articles 10, paragraph 3 , and 24 of the Covenant if there is a possibility of review and a prospect of release, notwithstanding the gravity of the crime they committed and the circumstances around it. That does not mean that release should necessarily be granted. It rather means that release should not be a mere theoretical possibility and that the review procedure should be a thorough one, allowing the domestic authorities to evaluate the concrete progress made by the authors towards rehabilitation and the justification for continued detention, in a context that takes into consideration the fact that they were 14 and 15, respectively, at the time they committed the crime. ${ }^{47}$

The Human Rights Committee has held that there are circumstances in which the recall of an offender on parole to continue serving his sentence in prison could be arbitrary and therefore contrary to the ICCPR. ${ }^{48}$ In a case where Spain amended its parole legislation to apply retrospectively which meant that the author had to serve his entire sentence without parole, the HRC held that it "cannot conclude that ... the denial of parole to the author made his imprisonment for the entire duration of his sentence arbitrary within the meaning of article 9, paragraph 1 , of the Covenant. 10."49 The HRC did not find New Zealand to be in violation of the Convention, although it amended its law to empower courts to impose lengthy nonparole periods and most importantly the Committee noted "in this respect that

46 Tai Wairiki Rameka, Anthony James Harris and Tai Rangi Tarawa $v$ New Zealand, U.N. Doc. CCPR/C/79/D/1090/2002 Communication No. 1090/2002 (November 6, 2003), para 7.3.

47 Communication No. 1968/2010, CCPR/C/112/D/1968/2010 (November 17, 2014), para 7.7.

48 Benjamin Manuel $v$ New Zealand, Communication No. 1385/2005, U.N. Doc. CCPR/C/91/D/1385/2005, para 7.3

49 José Luis De León Castro v Spain, U.N. Doc. CCPR/C/95/D/1388/2005 Communication No. 1388/2005 (March 19, 2009), para 9.3. 
release on parole in the State party's criminal justice scheme is neither an entitlement nor automatic, and is in part dependent on the author's own behaviour." 50 The HRC declared that parole legislation should be implemented in a non-discriminatory manner. ${ }^{51}$ It is clear that the Human Rights Committee has held that an offender does not have a right to be released on parole. However, there has to be a prospect that the offender will be released.

Like the ICCPR, the African Charter on Human and Peoples' Rights is silent on the right to parole. The African Commission on Human and Peoples' Rights is yet to hold that a prisoner has a right to parole. However, the African Commission has recommended to some states parties to the African Charter on Human and Peoples' Rights to amend their laws and provide for parole. ${ }^{52}$ In the light of the fact that many countries, including all of the countries discussed below, ${ }^{53}$ have ratified the ICCPR and in some countries, such as South Africa, courts are empowered to refer to international law and foreign law in interpreting legislation relevant to human rights, it is imperative to look at the issue of the right to parole in some countries where it has been considered. This is important because of the relationship between the placement of an offender on parole and his or her rehabilitation has been dealt with by the Human Rights Committee. The Human Rights Committee has taken a position that an offender should have the prospect of being released. National legislation or policies which do not provide for the real possibility of releasing offenders on parole are likely to be criticised by the Human Rights Committee and states will have to amend them to comply with their international obligations especially under Article 10(3) of the ICCPR. One country, the Netherlands, is a state party to both the European Convention on Human Rights and the ICCPR; the discussion above on the right to parole by both these bodies is likely to influence its legislation and policies on parole.

50 Ronald van der Plaat $v$ New Zealand, Communication No. 1492/2006, U.N. Doc. CCPR/C/93/D/1492/2006 (July 22, 2008), para 6.4.

51 Kang $v$ Republic of Korea, Comm. 878/1999, U.N. Doc. A/58/40, Vol. II, at 152 (HRC 2003), para 7.2.

52 See for example, "Namibia: Mission on Prisons and Conditions of Detention - 2001" //

http://www.achpr.org/states/namibia/missions/prisons-2001/; "Malawi: Mission on Prisons and Conditions of Detention, 2001" // http://www.achpr.org/states/malawi/missions/prisons-2001/.

53 These countries ratified or acceded to the ICCPR in the following years: Vanuatu (2008); Australia (1980); Canada (1976); South Africa (1998); United States of America (1992); South Korea (1990); the Netherlands (1978); and India (1979). See:

https://treaties.un.org/Pages/ViewDetails.aspx?src=IND\&mtdsg_no=IV-4\&chapter=4\&lang=en. 


\title{
4. NATIONAL JURISDICTIONS AND THE ISSUE OF PAROLE: SOUTH AFRICA, THE UNITED STATES OF AMERICA, SOUTH KOREA, AUSTRALIA, THE NETHERLANDS, VANUATU, CANADA, AND INDIA
}

This article focuses on countries on which the author was able to find case law or legislation dealing with the right to parole. The first example is South Africa. South African legislation does not provide for the offender's right to parole. South African courts have taken five different approaches on the issue of whether the offender has a right to be released on parole. In the first category you find cases in which courts have held that an offender has no right to be released on parole. For example, in Du Preez v Minister of Justice and Correctional Services and Others ${ }^{54}$ the court held that a prisoner has no right to parole and also has no right to resist the revocation of parole. ${ }^{55}$ In the second category one finds cases where courts have held that an offender has the right to parole. For example, in Mafoho $v S^{56}$ the Supreme Court of Appeal observed that:

\begin{abstract}
The issue accordingly, is the effect of the amendment of the parole period in $\mathrm{s}$ 65(4) of the old Act, upon the appellant's right to parole. By virtue of the fact that $s$ 65(4) of the old Act, was amended on the same date that the provisions of $s$ 73(6)(a) of the new Act were brought into operation, it is clear that the intention of the legislature was to create equality amongst those prisoners eligible for parole, irrespective of whether they were sentenced before or after the passing of the new Act. The right to parole, whether the prisoner is sentenced to a determinate sentence, or to life imprisonment, is the same regardless of the date the prisoner was sentenced. ${ }^{57}$
\end{abstract}

Similarly, in Wiggil $v S,{ }^{58}$ in which the appellant's previous conviction was considered for the purpose of imposing a subsequent sentence, the court observed that "[h]ad the magistrate ordered that the sentence run concurrently with that imposed in the previous matter, she would, in effect, not have been punished for this offence save insofar as it may have had a potential effect on her right to parole in the future. ${ }^{\prime 59}$ In the third category one finds cases in which courts have held that an offender has a right to be considered for parole after serving the prescribed minimum term of imprisonment (non-parole period). For example, in Van Gund $v$ Minister of Correctional Services and Others ${ }^{60}$ the court held that:

\footnotetext{
${ }^{54}$ Du Preez v Minister of Justice and Correctional Services and Others, 2015 (1) SACR 478 (GP).

55 Ibid., paras 9 and 12.

56 Mafoho v S., 2013 (2) SACR 179 (SCA).

57 Ibid., para 17.

58 Wiggil v S., (CA \& R 137/2012) [2012] ZAECGHC 90 (November 21, 2012).

59 Ibid., para 8.

60 Van Gund v Minister of Correctional Services and Others, 2011 (1) SACR 16 (GNP).
} 
It is trite law that a prisoner has no right to be released on parole. He, however, has a right to be considered. Furthermore once an offender has been lawfully sentenced by a court of law he or she has no right to liberty. That right to liberty is deprived by process of law after he/she has been sentenced. The right to be considered for parole should not be equated to the right to be freed from prison. That right only arises once the [Parole] Board decides to grant parole. The right to be considered for parole is an administrative action and consequently a prisoner is entitled to a fair procedure. Section 33 of the Constitution of the Republic of South Africa Act No. 108 of 1996 provides that "Everyone has the right to administrative action that is lawful, reasonable and procedurally fair". ${ }^{61}$

The court in the above decision mentions two important rights: the right to be considered for parole and that right to the released from prison. The latter right only arises once the offender has been granted parole. In other words, it is not a right to parole. This reasoning has been followed in subsequent high court decisions. ${ }^{62}$ In another case, the high court held that:

The granting of parole is not a right that can be claimed by an applicant, it is a privilege as in terms of section 73(1)(a) of the Correctional Services Act...a sentenced offender is to remain in correctional centre for a full term of his sentence subject to the provisions of section 73(6)(a). The Act makes provision for consideration of placement on parole and not the actual placement on parole. What a sentenced offender ... enjoys is the right to be considered for parole. ${ }^{63}$

The Constitutional Court ${ }^{64}$ and other divisions of the high court have also observed that an offender has a right to be considered for parole. ${ }^{65}$ This means that the offender will have to be considered for placement on parole whether or not he makes an application to the parole board to be considered for parole. The question is: at what stage does the offender's right to be considered for parole arise? In $S \vee$ Bull and Another ${ }^{66}$ the Supreme Court of Appeal held that the lengthy sentence imposed on the offender "could be unjustified as it would deprive the accused of the right to be considered for parole when he might no longer be dangerous." 67 This reasoning has been followed in subsequent case law. ${ }^{68}$ Implied

61 Ibid., para 11 [footnotes omitted].

62 Freddie v Minister of Correctional Services and Others, (19293/2006) [2011] ZAGPPHC 54 (April 6, 2011), para 8.

63 Shebe $v$ Minister of Correctional Services and Others, (2338/2013) [2013] ZAFSHC 154 (September 19, 2013), para 7.

${ }^{64}$ Van Vuren $v$ Minister of Correctional Services and Others, 2010 (12) BCLR 1233 (CC); 2012 (1) SACR 103 (CC), para 103

65 Makaba $v$ Minister of Correctional Services and Others, (5369/2011) [2012] ZAFSHC 157 (August 16, 2012), para 29; Mtintso v S, (A1038/2013) [2015] ZAGPPHC 213 (April 21, 2015), para 3; Bester $v$ Minister of Correctional Services and Others, (64018/09) [2012] ZAGPPHC 318 (November 28, 2012), para 7; Groenewald v Minister of Correctional Services and Others, (67533/09) [2010] ZAGPPHC 6; 2011 (1) SACR 231 (GNP), para 16.

66 S v Bull and Another, (221/2000) [2001] ZASCA 105 (September 26, 2001).

67 Ibid., para 28.

68 S v Sekiti, 2010 (1) SACR 622 (ECG), para 14. 
in this statement is that an offender has to be considered for parole when he was no longer dangerous. It is argued that this reasoning is debatable in the light of the jurisprudence emanating from the European Court of Human Rights and the Human Rights Committee as discussed above. ${ }^{69}$ The reason why an offender is being considered for parole is to determine whether or not he should be placed on parole. If the parole board finds that he is dangerous, then he is not released on parole. Whether or not he is dangerous he has to be considered for parole for the decision to be made whether or not he should be released on parole. In the fourth category one finds jurisprudence to the effect that an offender has "the right to apply for parole."70 This means that if he does not exercise this right, he may not be considered for parole. The challenge is that the Correctional Services Act does not provide that an offender has a right to apply for parole. As the Supreme Court of Tasmania (Australia) held in Oates $v$ Parole Board, ${ }^{71}$ where the legislation does not provide for the offender's right to parole or to apply for parole, "[t]here is no right to parole, nor is there any right to apply for it. In strict terms, the Board is obliged to consider only once the eligibility of a prisoner to be released on parole, and that is before his or her eligibility date. ${ }^{172}$ In the fifth category one finds a Constitutional Court judgement to the effect that an offender should not "be denied the opportunity to be considered for parole."73 In other words, being considered for parole is an opportunity as opposed to a right.

Courts in the United States of America have held that an offender does not have right to parole. For example, in Sweeton $v$ Brown ${ }^{74}$ the United States Court of Appeals (Sixth Circuit), referring to the earlier jurisprudence from Michigan Court of Appeals, the Court held that "the early parole provision of the Michigan statute created only an expectation or hope of an early parole. Therefore, the court held that the statute did not create a right to parole. This is in accordance with our current views." 75 However, whether or not a prisoner has a limited right to parole will depend on the statute of the relevant state. ${ }^{76}$ In the Netherlands an offender does not have a right to be released on parole. ${ }^{77}$ In Canada, courts have also held

\footnotetext{
69 South African Courts are obliged to refer to international law when interpreting the Bill of Rights. Section 39(1)(b) of the Constitution of South Africa (1996) provides that "(1) When interpreting the Bill of Rights, a court, tribunal or forum must consider international law." South African courts have considered jurisprudence from the European Court of Human Rights and the Human Rights Committee in interpreting the Bill of Rights. See S v Makwanyane and Another, 1995 (6) BCLR 665; 1995 (3) SA 391; [1996] 2 CHRLD 164; 1995 (2) SACR 1; Lufuno Mphaphuli \& Associates (Pty) Ltd $v$ Andrews and Another, 2009 (4) SA 529 (CC); 2009 (6) BCLR 527 (CC).

70 Nyawuza v S, (AR 262/13) [2014] ZAKZPHC 47 (September 16, 2014), para 8 and footnote 7.

71 Oates $v$ Parole Board, [2013] TASSC 10 (April 8, 2013).

72 Ibid., para 9.

73 Jimmale and Another v S, (CCT223/15) [2016] ZACC 27 (August 30, 2016), para 23.

74 Sweeton v Brown, [1991] USCA6 1769; 944 F.2d 905 (September 17, 1991).

75 Ibid., footnote 4.

76 Evans v W H Dillahunty E, [1981] USCA8 646; 662 F.2d 522 (November 2, 1981).

77 Murray $v$ The Netherlands, Application no. 10511/10 (December 10, 2013), para 93.
} 
that an offender does not have a right to be released on parole. ${ }^{78}$ However, an offender has a right to be considered for parole after serving the statutory nonparole period. ${ }^{79}$ In Chaudhry v. Canada (Minister of Citizenship and Immigration) the Court held that:

Even though Parliament may not be constitutionally required to provide for parole, once it has created a statutory eligibility for parole, day or full, denial of the statutory right to be considered for it may constitute a detention because it causes the person concerned to serve his or her sentence under significantly more restrictive conditions than those applicable to the general inmate population. And if the statutory right is removed without any kind of hearing or a review of its continuation, then the person's detention is surely arbitrary. ${ }^{80}$

However, in Canada a prisoner has "a right to parole should one's physical/mental health is likely to suffer serious damage on account of continued incarceration. "81 In some cases some Canadian courts have held, though in passing, that an offender has a right to parole. ${ }^{82}$

Article 72(1) of the Criminal Act of South Korea provides that "a person under execution of imprisonment or imprisonment without prison labor who maintains good behavior and has shown a sincere repentance may be provisionally released by administrative action when ten years of a life sentence or one-third of a limited term of punishment has been served." The Constitutional Court of Korea held that:

Parole is a privilege conferred upon an inmate by the law enforcement agency according to decisions based on correctional or criminal policies. An inmate who has met requirements prescribed in Article 72(1) of the Criminal Act does not automatically obtain a subjective right to demand parole release, and the administrative authority is not legally bound to release the inmate on parole. An inmate can enjoy the benefit of release before the expiry of his sentence only when there is a specific administrative disposition to release an inmate on parole based on Article 72(1) of the Criminal Act ... .83

In Knight $v$ Money $^{84}$ the Supreme Court of Victoria (Australia) held that an offender who has served the non-parole period does not have a right to parole. He is only eligible for parole. This means that he may or may not be released on

78 Ginther $v$ Saskatchewan Government Insurance, 1987 CanLII 4605 (SK QB) para 15; $R$ v Neale, 1985 CanLII 1197 (AB QB), para 59; Mitchell $v$ R, [1976] 2 SCR 570, 1975 CanLII 167 (SCC), p. 588.

79 Hutchins $v$ Canada (National Parole Board), [1993] 3 FCR 505, 1993 CanLII 2981 (FCA); $R v$ Yarema, 2006 CanLII 23953 (ON SC), para 16; $R$ v Chaudhary, 1999 CanLII 14902 (ON SC), para 12; $R v$ Dell, 2015 ONSC 1570 (CanLII), para 26.

80 Chaudhry v. Canada (Minister of Citizenship and Immigration), [1999] 3 FCR 3, 1999 CanLII 7631 (FC), para 43.

${ }^{81} R$ v Precup, 2015 ONSC 2112 (CanLII).

${ }^{82}$ Canada (Attorney General) v. Coscia, 2005 FCA 132 (CanLII), para 23; and Woodhouse v. Canada (Correctional Service), 2010 BCSC 754 (CanLII), para 237.

83 Pledge to Abide by the Law Case 98Hun-Ma425, [2002] KRCC 4 (April 25, 2002) //

http://www.worldlii.org/cgi-bin/sinodisp/kr/cases/KRCC/2002/4.html.

84 Knight $v$ Money, [2015] VSC 105 (March 24, 2015). 
parole. The Supreme Court of New South Wales (Australia) referred to jurisprudence from other courts and held that " $[\mathrm{t}]$ he granting of parole by a parole authority has been held to be a privilege and not a right." 85 The Supreme Court of Tasmania held that legislation which gives the court the discretion to impose a nonparole period "give no prima facie right to parole eligibility." 86 The Court had held in an earlier decision referring to the same legislative provision that "[t]here is no statutory right to parole. ${ }^{\prime 87}$ The Supreme Court of Western Australia held that an offender has a "right to be considered for parole." 88 However, the right to be considered for parole only arises once the offender has completed serving the nonparole period. ${ }^{89}$ In some jurisdictions there is legislation which obliges the parole authorities to release an offender on parole after serving a portion of the sentence. For example, section 66(1) of the South Australian Correctional Services Act provides that:

(1) Subject to subsection (2), the Board must order that a prisoner who is liable to serve a total period of imprisonment of less than five years and for whom a non-parole period has been fixed be released from prison or home detention on parole on a day specified by the Board, being a day - (a) where, because the commencement of the non-parole period has been back dated, the non-parole period expires prior to the date on which it is fixed, not later than 30 days after the day on which it is fixed; or (b) in any other case, not later than 30 days after the day on which the non-parole period expires.

In $R \vee$ Franceschini 90 the Supreme Court of South Australia held that "[u]nder section 66 of the Correctional Services Act, some types of prisoners have an automatic right to parole at the expiration of a non-parole period of less than five years." ${ }^{\prime 1}$ In other words, an offender who was sentenced to more than five years' imprisonment "has no automatic right to parole." 92 The position is also the same in Turkey $^{93}$ and there evidence that some offenders have been granted automatic parole. ${ }^{94}$ The Court of Appeal of Vanuatu, without elaborating, imposed two sentences on an offender and ordered that they should run concurrently "subject to

\footnotetext{
85 Moefili v State Parole Authority \& Anor, [2009] NSWSC 1146 (October 29, 2009), para 43.

86 E v State of Tasmania, [2008] TASSC 72 (November 20, 2008), para 20 (the Court was referring to section 17 of the Sentencing Act, 1997).

87 Devine v Tasmania, [2006] TASSC 104 (December 1, 2006), para 2.

${ }^{88}$ Little $v$ The State of Western Australia, [2007] WASC 33 (February 9, 2007), para 51.

89 NGJF v Prisoners Review Board, [2010] WASC 107 (May 21, 2010), para 67.

90 R v Franceschini, [2015] SASCFC 116 (August 17, 2015).

91 Ibid., para 29. See also Manning v Police, [2015] SASC 49 (March 27, 2015), para 9.

$92 R$ v Abdulla, [2011] SASCFC 20 (April 1, 2011), para 34.

93 Erdoğdu and İnce $v$ Turkey, Applications nos. 25067/94 and 25068/94 (July 8,1999 ), para 19; Sürek v Turkey (No. 1), Application no. 26682/95 (July 8, 1999), para 24; Gerger v Turkey, Application no. 24919/94 (July 8, 1999), para 20.

94 Okçuoğlu v Turkey, Application no. 24246/94 (July 8, 1999), para 13
} 
the right to parole." 95 The Supreme Court Vanuatu took into consideration the time the offender had spent in custody awaiting trial in calculating the sentence to impose of him because it did not want him to lose his "right of Parole." high court held that an offender has a right to parole. ${ }^{97}$

\section{CONCLUSION}

The above discussion has shown that generally in international human rights law an offender does not have a right to be released on parole. However, once he has served the non-parole period, he has to be considered for parole and his continued imprisonment has to be justified by compelling reasons. The same approach has also been followed in some of the jurisdictions discussed in this article. In Australia where courts have held that an offender has the right to parole, this has been so because legislation provides for that right. In South Africa courts have taken different approaches on the question of whether an offender has the right to parole. Therefore, Judge Pinto De Albuquerque's decision that an offender has a right to parole should be understood in the context in which it was made and especially in the light of the three guarantees that he held must be in place for this right to be realised. But the soundness of his conclusion should not be dismissed easily. The right to parole he refers to arises when the offender's continued imprisonment cannot be justified. This means that the right to parole arises at the time when the offender justifiably qualifies for it. This is the same with some other rights. For example, the right to healthcare only arises when a person can justifiably claim it - when that person is sick; the right to not to be denied emergency medical treatment arises when a person needs that treatment; and the right to vote arises when a person is of voting age and meets other requirements such as citizenship. It should also be noted that the list of human rights is not closed. Whenever society advances to another level of development new rights emerge. In the light of the fact that imprisonment is used in all parts of the world and that the issue of the release of offenders on parole has started to attract the attention of international and regional human rights bodies, the time has come for this right to be given enough attention in national and international human rights instruments. The moment the right to parole is recognised, it is accompanied by some obligations. As some judges of the European Court of Human Rights

\footnotetext{
95 Boesaleana v Public Prosecutor, [2011] VUCA 33; Criminal Appeal 07 of 2011 (November 25, 2011), para 27.

96 Public Prosecutor v Alfred, [2008] VUSC 35; Criminal Case 23 of 2008 (April 18, 2008).

97 Smt Suman v State Of Raj And Anr, CW Case No. 1665 of 2007 [2007] INRJHC 4159 (August 23, 2007).
} 
observed, there is a clear distinction between 'right' on the one hand and 'privilege' on the other hand.

This differentiation has many decisive legal implications. Rights, especially in criminal law, require restrictive substantive criteria (lex certa, lex clara, principle of legality, etc.) and strict procedural formalism - whereas privileges (clemency, rewards, awards, prizes, honours, etc.) do not. Rights and duties lend themselves to legal remedies and regulation, whereas privileges do not. To confuse the two, in other words to say that the prisoner now has ex lege the right (or the enforceable "legitimate expectation") to be released, rather than a privilege resulting from his morally desirable "good behaviour", makes the law defeat precisely what it is intended to defend, namely the accepted wisdom of parole. If the law makes the conditional release a right rather than a privilege, it effectively deprives the prisoner of his motivation to improve. ${ }^{98}$

However, there are some problems associated with parole in some European countries. There is evidence from some European countries that some offenders who have been released on parole have reoffended before the expiry of the parole period. ${ }^{99}$ There have been allegations in some countries such as Lithuania, 100 Russia, ${ }^{101}$ and the United Kingdom, ${ }^{102}$ that prison authorities have promised some prisoners early placement on parole if they conduct some activities for the prison authorities or make statements in support of the government's case. There have also been credible reports that in one country prisoners have bribed a prison official to be placed on parole. ${ }^{103}$ Whether or not these offenders have been rehabilitated is immaterial as long as they have done what the prison authorities asked them to do in exchange for placement on parole. This means that prison authorities may manipulate the process and place on parole offenders who do not qualify for parole, hence putting the public at risk. It should also be mentioned in passing that even in international criminal law there are mechanisms to ensure that an offender is not

98 Ezeh and Connors $v$ The United Kingdom, supra note 1, para 13 (Dissenting Opinion of Judges Zupančič and Maruste).

99 Mastromatteo v Italy, Application no. 37703/97 (October 24, 2002) (the applicant's son was murdered by a prisoner on parole); Birulev and Shishkin v Russia, Applications nos. 35919/05 and 3346/06 (June $14,2016)$ (the applicant was arrested for being in possession of a stolen car three days after his placement on parole for a similar offence); Kazantsev $v$ Russia, Application no. 14880/05 (April 3, 2012), para 18

100 Valašinas $v$ Lithuania, Application no. 44558/98 (July 24, 2001), para 27: "Many prisoners were allegedly employed as secret informers by the administration, in return for promises of parole or conditional release."

101 Novinskiy v Russia, Application no. 11982/02 (February 10, 2009), para 51, where the applicant alleged that "his earlier retraction of the statement of 25 April 2006 had been due solely to the fact that at the relevant time he had applied for release on parole and that the prison officials had made insinuations and disguised remarks to the effect that his application for release might not be granted unless he retracted." The Court agreed that there circumstances of the case indicated that some pressure was put on the applicant by the state authorities. See paras $120-122$. See also Karpenko $v$ Russia, Application no. 5605/04 (March 13, 2012), para 28

102 Rowe and Davis $v$ The United Kingdom, Application no. 28901/95 (February 16, 2000), para 20, state witness allegedly lying in court to qualify for parole.

${ }^{103}$ Puzan v Ukraine, Application no. 51243/08 (February 18, 2010), para 20. 
imprisoned for the rest of his natural life. Jurisprudence emanating from the International Criminal Tribunal for the Former Yugoslavia, the International Criminal Tribunal for Rwanda ${ }^{104}$ and the Residual Special Court for Sierra Leone ${ }^{105}$ show that offenders sentenced to imprisonment by those courts have been released early, before completing their sentences, although the statutes of these tribunals do not use the word 'parole.' However, the Trial Chamber of the Extraordinary Chambers in the Courts of Cambodia held that "[t]he fact that the founding documents of this sui generis special intemationalised tribunal do not contain parole provisions indicates that the drafters did not envision that parole would be available for the convicted accused of this Court."106 This practice from the international human rights bodies and criminal tribunals shows that an offender does not have the right to be released on parole although he has to be considered for parole or early release after serving a given number of years. In light of the jurisprudence emanating from the European Court of Human Rights and from the Human Rights Committee, it would be contrary to human rights law if an international criminal tribunal were to be empowered by its establishing statute to impose a sentence of life imprisonment without the prospect of parole or early release irrespective of the fact that the offender has been rehabilitated and he/she is no longer a danger to society.

\section{BIBLIOGRAPHY}

1. Choi, Jonathan H. "Early Release in International Criminal Law." Yale Law Journal 6 (123): 1784-1828.

2. European Committee on Crime Problems, Council for Penological Cooperation. "Dangerous Offenders Country Survey." PC-CP (2010) 04 (March $15,2010) / /$

http://www.coe.int/t/dghl/standardsetting/prisons/PCCP\%20documents\%202 010/PC-CP(2010)04_E\%20_Dangerous\%200ffenders\%20per\%20Country.pdf.

3. Holá, Barbora, and Joris van Wijk. "Life after Conviction at International Criminal Tribunals: An Empirical Overview." J Int. Criminal Justice 12 (1) (2014): 109-132.

\footnotetext{
104 Barbora Holá and Joris van Wijk, "Life after Conviction at International Criminal Tribunals: An Empirical Overview," J Int Criminal Justice 12 (1) (2014); Jonathan H. Choi, "Early Release in International Criminal Law," Yale Law Journal 6 (123).

105 Jamil Ddamulira Mujuzi, "The Conditional Early Release of Offenders Transferred from the Special Court for Sierra Leone to Serve Their Sentences in Designated States: Some Observations and Recommendations," African Yearbook on International Humanitarian Law (2014).

${ }_{106}$ Co-Prosecutors v Kaing, Co-Prosecutors' Appeal Against the Judgement of the Trial Chamber in the Case of Kaing Guek Ea V Alias Ouch, 001/18-07-2007-ECCC/SC (ECCC SC, Oct. 13, 2010), para 125. However, see Co-Prosecutors $v$ Kaing, Appeal Judgement, F28; 001/18-07-2007-ECCC/SC (ECCC SC, Feb. 03, 2012), paras $384-388$, where the Appeals Chamber did not rule out the possibility of parole.
} 
4. "Intervention in the Council for Penological Co-Operation." Fourth Plenary Meeting (November 5, 2014) //

http://www.coe.int/t/DGHL/STANDARDSETTING/PRISONS/PCCP\%20documen ts\%202014/CEDH\%20intervention\%20PC-

CP\%20plenary\%20November\%202014.pdf.

5. "Malawi: Mission on Prisons and Conditions of Detention, 2001" //

http://www.achpr.org/states/malawi/missions/prisons-2001/.

6. Mujuzi, Jamil Ddamulira. "The Conditional Early Release of Offenders Transferred from the Special Court for Sierra Leone to Serve Their Sentences in Designated States: Some Observations and Recommendations." African Yearbook on International Humanitarian Law (2014): 154-170.

7. "Namibia: Mission on Prisons and Conditions of Detention - 2001" // http://www.achpr.org/states/namibia/missions/prisons-2001/.

8. Nowak, Manfred. "U.N. Covenant on Civil and Political Rights: CCPR Commentary" (1993): 191-192.

9. "Report to the Bulgarian Government on the visit to Bulgaria carried out by the European Committee for the Prevention of Torture and Inhuman or Degrading Treatment or Punishment (CPT) from 15 to 19 December 2008." CPT/Inf (2010) 29.

10. "Report to the Bulgarian Government on the visit to Bulgaria carried out by the European Committee for the Prevention of Torture and Inhuman or Degrading Treatment or Punishment (CPT) from 4 to 10 May 2012." CPT/Inf (2012) 32.

11. Zyl Smit, Dirk van, Pete Weatherby, and Simon Creighton. "Whole Life Sentences and the Tide of European Human Rights Jurisprudence: What Is to Be Done?" Human Rights Law Review 14 (2014): 59-84.

\section{LEGAL REFERENCES}

1. Arvydas Živulinskas $v$ Lithuania. Application no. 34096/02 (December 12, 2006).

2. Aswat $v$ The United Kingdom. Application no. 17299/12 (April 16, 2013).

3. Babar Ahmad and Others $v$ The United Kingdom. Applications nos. 24027/07, 11949/08, 36742/08, 66911/09 and 67354/09 (April 10, 2012).

4. Benjamin Manuel $v$ New Zealand. Communication No. 1385/2005, U.N. Doc. CCPR/C/91/D/1385/2005.

5. Bester $v$ Minister of Correctional Services and Others. 64018/09 [2012] ZAGPPHC 318 (November 28, 2012). 
6. Birulev and Shishkin v Russia. Applications nos. 35919/05 and 3346/06 (June 14, 2016).

7. Blackstock $v$ The United Kingdom. Application no. 59512/00 (June 21, 2005).

8. Boesaleana $v$ Public Prosecutor. VUCA 33, Criminal Appeal 07 of 2011 (November 25, 2011).

9. Čačko v Slovakia. Application no. 49905/08 (July 22, 2014).

10. Canada (Attorney General) v Coscia. 2005 FCA 132 (CanLII).

11. Chaudhry $v$ Canada (Minister of Citizenship and Immigration). [1999] 3 FCR 3, 1999 CanLII 7631 (FC).

12. Clift $v$ The United Kingdom. Application no. 7205/07 (July 13, 2010).

13. Communication No. 1968/2010, CCPR/C/112/D/1968/2010 (November 17, 2014).

14. Co-Prosecutors v Kaing, Co-Prosecutors' Appeal Against the Judgement of the Trial Chamber in the Case of Kaing Guek Ea V Alias Ouch. 001/18-07-2007ECCC/SC (ECCC SC, Oct. 13, 2010).

15. Co-Prosecutors $v$ Kaing. Appeal Judgement, F28, 001/18-07-2007-ECCC/SC (ECCC SC, Feb. 03, 2012).

16. Curley $v$ The United Kingdom. Application no. 32340/96 (March 28, 2000).

17. David Thomas $v$ The United Kingdom. Application no. 55863/11 (November 4, 2014).

18. Del Río Prada v Spain. Application no. $42750 / 09$ (October 21, 2013).

19. Devine $v$ Tasmania. [2006] TASSC 104 (December 1, 2006).

20. Dillon $v$ The United Kingdom. Application no. 32621/11 (November 4, 2014).

21. Du Preez v Minister of Justice and Correctional Services and Others. 2015 (1) SACR 478 (GP).

22. E v State of Tasmania. [2008] TASSC 72 (November 20, 2008).

23. Erdoğdu And İnce $v$ Turkey. Applications nos. 25067/94 and 25068/94 (July 8, 1999).

24. Evans $v$ W H Dillahunty E. [1981] USCA8 646; 662 F.2d 522 (November 2, 1981).

25. Ezeh and Connors $v$ The United Kingdom. Applications nos. 39665/98 and 40086/98 (October 9, 2003).

26. Freddie $v$ Minister of Correctional Services and Others. (19293/2006) [2011] ZAGPPHC 54 (April 6, 2011).

27. Gelfmann v France. Application no. 25875/03 (December 14, 2004).

28. Gerger v Turkey. Application no. 24919/94 (July 8, 1999).

29. Ginther v Saskatchewan Government Insurance. 1987 CanLII 4605 (SK QB). 
30. Groenewald $v$ Minister of Correctional Services and Others. (67533/09) [2010] ZAGPPHC 6; 2011 (1) SACR 231 (GNP).

31. Harakchiev and Tolumov $v$ Bulgaria. Applications nos. 15018/11 and 61199/12 (July 8, 2014).

32. Harkins and Edwards $v$ The United Kingdom. Application nos. 9146/07 and 32650/07 (January 17, 2012).

33. Hussain $v$ The United Kingdom. Application no. 21928/93 (February 21, 1996).

34. Hutchins v Canada (National Parole Board). [1993] 3 FCR 505, 1993 CanLII 2981 (FCA).

35. IVko v Russia. Application no. 30575/08 (December 15, 2015).

36. James, Wells and Lee $v$ The United Kingdom. Applications nos. 25119/09, 57715/09 and 57877/09 (September 18, 2012).

37. Jimmale and Another v S. (СCT223/15) [2016] ZACC 27 (August 30, 2016).

38. José Luis De León Castro $v$ Spain. U.N. Doc. CCPR/C/95/D/1388/2005 Communication No. 1388/2005 (March 19, 2009).

39. Kang $v$ Republic of Korea. Comm. 878/1999, U.N. Doc. A/58/40, Vol. II, at 152 (HRC 2003).

40. Karpenko v Russia. Application no. 5605/04 (March 13, 2012).

41. Kazantsev v Russia. Application no. 14880/05 (April 3, 2012).

42. Khoroshenko v Russia. Application no. 41418/04 (June 30, 2015).

43. Knight $v$ Money. [2015] VSC 105 (March 24, 2015).

44. Koryak v Russia. Application no. 24677/10 (November 13, 2012).

45. László Magyar v Hungary. Application no. 73593/10 (May 20, 2014).

46. Law on the Approval and Entry into Force of the Criminal Code. September 26, 2000, No VIII-1968 [As last amended on February 11, 2010 - No XI-677].

47. Léger v France. Application no. 19324/02 (March 30, 2009).

48. Little $v$ The State of Western Australia. [2007] WASC 33 (February 9, 2007).

49. Lufuno Mphaphuli \& Associates (Pty) Ltd $v$ Andrews and Another. 2009 (4) SA 529 (CC); 2009 (6) BCLR 527 (CC).

50. Mafoho v S. 2013 (2) SACR 179 (SCA).

51. Makaba v Minister of Correctional Services and Others. (5369/2011) [2012] ZAFSHC 157 (August 16, 2012).

52. Manning $v$ Police. [2015] SASC 49 (March 27, 2015).

53. Mastromatteo v Italy. Application no. 37703/97 (October 24, 2002).

54. Mitchell v. R. [1976] 2 SCR 570, 1975 CanLII 167 (SCC) p.588.

55. Moefili v State Parole Authority \& Anor. [2009] NSWSC 1146 (October 29, 2009). 
56. Mouisel v France. Application no. 67263/01 (November 14, 2002).

57. Mtintso v S. (A1038/2013) [2015] ZAGPPHC 213 (April 21, 2015).

58. Murray $v$ The Netherlands. Application no. 10511/10 (April 26, 2016).

59. Murray $v$ The Netherlands. Application no. 10511/10 (December 10, 2013).

60. NGJF v Prisoners Review Board. [2010] WASC 107 (May 21, 2010).

61. Nogin v Russia. Application no. 58530/08 (January 15, 2015).

62. Novinskiy v Russia. Application no. 11982/02 (February 10, 2009).

63. Nyawuza v S. (AR 262/13) [2014] ZAKZPHC 47 (September 16, 2014).

64. Oates $v$ Parole Board. [2013] TASSC 10 (April 8, 2013).

65. Öcalan v Turkey (No. 2). Applications nos. 24069/03, 197/04, 6201/06 and 10464/07 (March 18, 2014).

66. Okçuoğlu v Turkey. Application no. 24246/94 (July 8, 1999).

67. Oldham $v$ The United Kingdom. Application no. 36273/97 (September 26, 2000).

68. Österreichischer Rundfunk v Austria. Application no. 35841/02 (December 7, 2006).

69. Othman (Abu Qatada) $v$ The United Kingdom. Application no. 8139/09 (January 17, 2012).

70. Pledge to Abide by the Law Case 98Hun-Ma425. [2002] KRCC 4 (April 25, 2002) //

http://www.worldlii.org/cgi-bin/sinodisp/kr/cases/KRCC/2002/4.html.

71. Public Prosecutor v Alfred. [2008] VUSC 35; Criminal Case 23 of 2008 (April 18, 2008).

72. Puzan v Ukraine. Application no. 51243/08 (February 18, 2010).

73. $R$ v Abdulla. [2011] SASCFC 20 (April 1, 2011).

74. $R v$ Dell. 2015 ONSC 1570 (CanLII).

75. $R v$ Franceschini. [2015] SASCFC 116 (August 17, 2015).

76. $R v$ Precup. 2015 ONSC 2112 (CanLII).

77. $R$ v Yarema. 2006 CanLII 23953 (ON SC).

78. $R \vee$ Chaudhary. 1999 CanLII 14902 (ON SC) para 12; R. v Dell, 2015 ONSC 1570 (CanLII).

79. $R v$ Neale. 1985 CanLII 1197 (AB QB).

80. Rangelov $v$ Germany. Application no. 5123/07 (March 22, 2012).

81. Ronald van der Plaat $v$ New Zealand. Communication No. 1492/2006, U.N. Doc. CCPR/C/93/D/1492/2006 (July 22, 2008).

82. Rowe and Davis $v$ The United Kingdom. Application no. 28901/95 (February 16, 2000).

83. Rrapo v Albania. Application no. 58555/10 (September 25, 2012). 
84. Rumor v Italy. Application no. 72964/10 (May 27, 2014).

85. S $v$ Bull and Another. (221/2000) [2001] ZASCA 105 (September 26, 2001).

86. S v Makwanyane and Another. 1995 (6) BCLR 665; 1995 (3) SA 391; [1996] 2 CHRLD 164; 1995 (2) SACR 1.

87. S v Sekiti. 2010 (1) SACR 622 (ECG).

88. Shebe $v$ Minister of Correctional Services and Others. (2338/2013) [2013] ZAFSHC 154 (September 19, 2013).

89. Singh $v$ The United Kingdom. Application no. 23389/94 (February 21, 1996).

90. Smt Suman $v$ State Of Raj And Anr. CW Case No. 1665 of 2007 [2007] INRJHC 4159 (August 23, 2007).

91. Stafford $v$ The United Kingdom. Application no. 46295/99 (May 28, 2002).

92. Stoyan Mitev v Bulgaria. Application no. 60922/00 (January 7, 2010).

93. Sürek v Turkey (No. 1). Application no. 26682/95 (July 8, 1999).

94. Sweeton v Brown. [1991] USCA6 1769; 944 F.2d 905 (September 17, 1991).

95. Tai Wairiki Rameka, Anthony James Harris and Tai Rangi Tarawa $v$ New Zealand. U.N. Doc. CCPR/C/79/D/1090/2002 Communication No. 1090/2002 (November 6, 2003).

96. Thynne, Wilson and Gunnell $v$ The United Kingdom. Application no. 11787/85; 11978/86; 12009/86 (October 25, 1990).

97. Trabelsi v Belgium. Application no. 140/10 (September 4, 2014).

98. Valašinas v Lithuania. Application no. 44558/98 (July 24, 2001).

99. Van Gund $v$ Minister of Correctional Services and Others. 2011 (1) SACR 16 (GNP).

100. Van Vuren $v$ Minister of Correctional Services and Others. 2010 (12) BCLR 1233 (CC); 2012 (1) SACR 103 (CC).

101. Vasyukov v Russia. Application no. 2974/05 (April 5, 2011).

102. Vinter and Others $v$ The United Kingdom. Applications nos. 66069/09, 130/10 and 3896/10 (July 9, 2013).

103. Von Bülow $v$ The United Kingdom. Application no. 75362/01 (October 7, 2003).

104. Waite $v$ The United Kingdom. Application no. 53236/99 (December 10, 2002).

105. Weeks $v$ The United Kingdom. Application no. 9787/82 2 (March 1987).

106. Weiss $v$ Austria. Comm. No. 1821/2008, U.N. Doc. CCPR/C/106/D/1821/2008, Views (HRC, Oct. 24, 2012).

107. Wiggil v S. (CA \& R 137/2012) [2012] ZAECGHC 90 (November 21, 2012).

108. Woodhouse $v$ Canada (Correctional Service). 2010 BCSC 754 (CanLII).

109. Wynne $v$ The United Kingdom (no. 2). Application no. 67385/01 (October 16, 2003). 